\title{
PELATIHAN MS. OFFICE WARGA KELURAHAN PENGEMBANGAN PESERTA PROGRAM PAKET C PKBM AZ ZAHRA KOTA BANJARMASIN
}

\author{
Jumriadi $^{1}$, Andi Suci Anita², Mukhyar Amani ${ }^{3}$, Abdul Hafiz ${ }^{4}$, \\ Mahutma Gandhi ${ }^{5}$ \\ ${ }^{1}$ FHISIP, Administrasi Negara, Universitas Terbuka \\ ${ }^{2}$ FST, Agribisnis, Universitas Terbuka \\ ${ }^{3}$ FKIP, Pendidikan Biologi, Universitas Terbuka \\ ${ }^{4}$ FKIP, Pendidikan IPS, Universitas Terbuka \\ ${ }^{5}$ FKIP, PGSD, Universitas Terbuka \\ Email : jumriadi@ecampus.ut.ac.id
}

\begin{abstract}
ABSTRAK
Dunia pekerjaan sekarang dimana zamanya digital dibutuhkan kualifikasi khusus yang harus dimiliki oleh para pencari kerja, keterampilan komputer seperti Ms. Office menjadi salah satu kualifikasi khusus tersebut. Tim PkM UT Banjarmasin memberikan Pelatihan Ms. Office dalam mempersiapkan siswa Paket C pada PKBM Az-Zahra Banjarmasin untuk memasuki dunia kerja. Tujuan pelatihan ini adalah untuk meningkatkan kompetensi siswa Paket C pada PKBM Az Zahra Banjarmasin. Materi pelatihan komuter meliputi dasar-dasar komputer Microsoftt Office (Word, Excel dan Powerpoint). Kegiatan pelatihan menggunakan sistem dril yaitu perpaduan teori dengan praktik. Pada sesi praktik peserta mengerjakan latihan yang diberikan dan pendampingan dilakukan untuk memberikan arahan ada peserta. Evaluasi dilakukan diakhir pelaksanaan PkM, dari hasil evaluasi secara statistik menunjukkan pelatihan mampu meningkatkan kometensi peserta dalam menggunakan Microsoft Ofice (Word, Excel dan Powerpoint).
\end{abstract}

Kata Kunci : Pendidikan Non Formal, Paket C, Pelatihan Ms. Office.

\section{PENDAHULUAN}

Memasuki dunia kerja zaman sekarang ini tentunya dibutuhkan kualifikasi yang lebih menantang ketimbang tahun-tahun sebelumnya. Dimana zaman sekarang adalah zamannya digital, maka keterampilan komputer menjadi salah satu kualifikasi khusus yang harus dimiliki oleh para pencari kerja.

Demikian halnya bagi warga masyarakat Kelurahan Pengambangan yang mengikuti program paket $\mathrm{C}$ tentunya juga diperlukan keahlian di bidang komputer, sebagai bekal untuk memasuki dunia kerja.

Tempat pelaksanaan abdimas adalah warga masyarakat yang mengikuti program Paket C di PKBM Az Zahra di Kelurahan Pengambangan, yang berjumlah kurang lebih 25 orang. Adapun yang menjadi alasan utama dipilihnya lokasi PKBM Az Zahra di Kelurahan Pengambangan adalah 
berkenaan dangan saran/arahan LPPMUT yang dimuat dalam Panduan Kegiatan Abdimas 2017 - 2021, bahwa wilayah abdimas yang disarankan adalah masyarakat yang tinggal di sekitar kantor UT Banjarmasin.

PKBM Az Zahra di Kelurahan Pengambangan jaraknya relatif dekat dengan kantor UT Banjarmasin, sehingga diharapkan masyarakat di sekitar kantor UT Banjarmasin merasakan manfaat langsung kegiatan abdimas yang dilaksanakan dan merasakan keberadaan UT Banjarmasin, sehingga hal ini juga sekaligus sebagai upaya promosi Unversitas Terbuka khususnya pada Masyarakat di Kelurahan Pengambangan.

Ketika TIM PkM melakukan observasi awal di PKBM Az Zahra diketahui bahwa siswa yang mengikuti Paket $\mathrm{C}$ rata-rata berusia antara $20-30$ tahun dimana sebagian sudah bekerja. Umumnya para siswa tersebut bekerja pada sektor informal seperti buruh bengkel, salon, satpam, wiraswasta dan lainnya. Salah satu keahlian yang dibutuhkan para siswa Paket $\mathrm{C}$ dalam meningkatkan kompetensi khususnya pada bidang komputer seperti pengolah kata (Ms. Word), spreadsheet (Ms. Excel) dan presentasi (Ms. Powerpoint).
Namun, adanya keterbatasan dalam penguasaan komputer pada PKBM Az Zahra sehingga belum dapat dipenuhi. Dengan demikian, maka TIM PkM memberikan pelatihan Microsoft Office bagi siswa Paket C di PKBM Az Zahra sehingga mampu meningkatkan komputensi lulusan dalam mencari pekerjaan.

\section{KAJIAN TEORI \\ Microsoft Office}

Microsoft Office adalah paket software buatan Microsoft Coorporation yang dirancang untuk memudahkan tugas perkantoran. Dengan Microsoft Office kita bisa mengetik proposal, surat, laporan keuangan, presentasi, database karyawan, membuat logo, dan lain-lain.

Microsoft Office adalah sebutan untuk paket aplikasi perkantoran buatan Microsoft dan dirancang untuk dijalankan di bawah sistem operasi Windows. Beberapa aplikasi di dalam Microsoft Office yang terkenal adalah Excel, Word, dan PowerPoint.

\section{Microsoft Word (Ms. Word)}

Microsoft word atau microsoft office word adalah perangkat lunak pengolah kata (word processor) andalan microsoft. Pertama diterbitkan pada 
1983 dengan nama multi-tool word untuk Xenix, versi-versi lain juga dikembangkan untuk berbagai sistem operasi, misalnya DOS (1983), apple macintosh (1984), SCO UNIX, OS/2, dan microsoft windows (1989). Setelah menjadi bagian dari microsoft office sistem 2003 dan 2007 diberi nama microsoft office word.

\section{Microsoft Excel (Ms-Excel)}

Merupakan program aplikasi spreadsheet (lembar kerja elektronik) canggih yang paling populer dan paling banyak digunakan saat ini. Excel akan sangat membantu kita dalam hal menghitung, memproyeksikan, menganalisa dan mampu mempresentasikan data dalam bentuk tabel dengan berbagai jenis tabel yang disediakannya, mulai dari bentuk Bar, Grafik, Pie, Line dan banyak lagi.

\section{Microsoft PowerPoint}

\section{(Ms. PowerPoint)}

Microsoft PowerPoint merupakan salah satu program presentasi yang paling sering digunakan. Kita biasa menyebutnya dengan sebutan PPT atau PowerPoint saja. Dengan Microsoft PowerPoint kita bisa membuat softcopy file yang akan kita gunakan untuk presentasi di dalam ruangan untuk berbagai acara seperti rapat.

\section{METODE PELAKSANAAN}

Metode pelaksanaan kegiatan ini adalah pelatihan sistem drill dengan perpaduan teori dan praktik serta diskusi dan unjuk kerja hasil pelatihan di akhir pelatihan. Pemahaman dan penguatan praktik komputer Ms. Office dengan menggunakan 1 komputer, satu peserta. Kegiatan Pengabdian Kepada Masyarakat ini menekankan praktik individu dengan didampingi secara bergiliran oleh TIM PkM. Pelaksanaan kegiatan pelatihan Ms. Office dilakukan sebanyak 4 kali pelatihan.

Kegiatan Pengabdian Kepada Masyarakat ini dibagi dalam tiga tahap yaitu persiapan, pelaksanaan, dan evaluasi. Tahap pertama persiapan yang dilakukan adalah menganalisa masalah dan kebutuhan dengan cara mencari data dan informasi melalui observasi ke PKBM Az Zahra. Pada tahap ini mengidentifikasi masalah dan mencari upaya untuk membantu mengatasi masalah yang muncul. Tahap kedua yaitu pelaksanaan pelatihan yang terbagi menjadi beberapa sesi, yaitu pembukaan, penyampaian teori dan praktik serta model pengajaran praktik Ms. Office, 
dilanjutkan dengan materi yang lebih aplikatif yaitu pembelajaran praktik melalui media komputer yang terbagi satu-satu. Kegiatan Pengabdian Kepada Masyarakat ini ditutup dengan laporan hasil/praktik dari para peserta. Di tahap akhir peserta menunjukan hasil yang di dapat selama pelatihan baik secara teori maupun praktik. Kemudian melakukan evaluasi sebagai tahap terakhir. Evaluasi ini dilakukan dengan meminta unjuk kerja peserta pelatihan.

\section{HASIL PELAKSANAAN PkM DOSEN}

Kegiatan pelatihan Ms. Office Warga Kelurahan Pengambangan Peserta Program Paket C PKBM Az Zahra Kota Banjarmasin dalam rangka memberikan keterampilan (soft skill) yang tidak mereka dapat di program paket C.

Hasil dari kegiatan pelatihan Ms. Office bagi Warga Kelurahan Pengambangan Peserta Program Paket C PKBM Az Zahra Kota Banjarmasin yaitu menambah pengetahuan dan keterampilan Ms. Office (Word, Excel dan Power Point) yang sangat berguna setelah mereka nantinya memasuki dunia kerja.
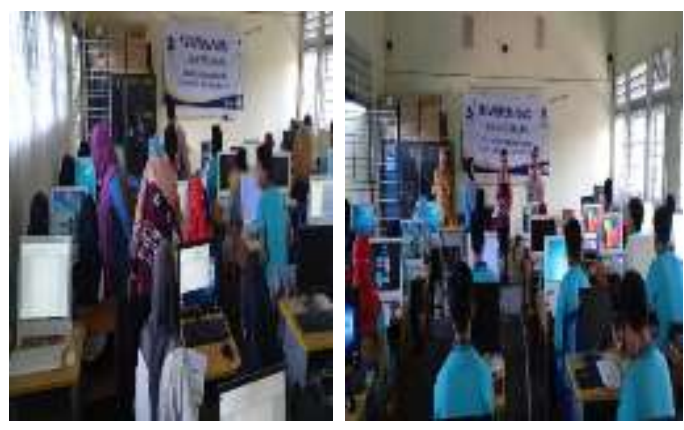

Panduan Dasar Ms. Word

Untuk menjalankan MS Word

diperlukan langkah sebagai berikut:

- hidupkan komputer/Laptop buka icon MS Word.

- Cara mengetik: Untuk mulai menulis di MS Word maka yang dilakukan adalah dengan langsung mengetik menggunakan keyboard. Bila kursor belum tampak maka cukup klik dulu dengan 'klik kiri/biasa' di baris paling atas halaman yang berwarna putih polos tersebut agar ketikannya mulai dari baris awal.

- Cara Menghapus Kata atau Kalimat: Untuk melakukan ini maka cukup dengan meletakkan kursor di depan tulisan (sebelah kiri kata pertama) lalu tekan tombol "Delete" di keyboard atau bisa juga letakkan kursor di sebelah kiri (belakang kata) dari kata atau kalimat yang akan dihapus lalu tekan tombol "Backspace" di keyboard. Bisa juga dalam belajar MS word ini kita mencari jalan pintas, misalnya pada cara ini kita cukup 
blok dulu kalimat atau paragraf yang akan dihapus lalu tekan tombol 'delete'.

- Cara Membuat Paragraf Baru atau pindah ke baris selanjutnya: Misalnya saja sudah selesai menulis 1 kalimat lalu mau lanjut di baris selanjutnya maka cukup tekan tombol "Enter" di keyboard.

- Cara Membuat Huruf besar dan kecil: Caranya tekan tombol "Caps Lock" yang ada di sebelah kiri Keyboard. Tekan sekali untuk mengaktifkan huruf Besar atau Kapitalnya dan tekan sekali lagi untuk mengembalikan jadi huruf kecil lagi.

- Cara Copy-Paste: Seringkan dengar istilah ini. Caranya cukup Blok dulu tulisannya kemudian tekan tombol Ctrl di pojok kiri bawah dan huruf $\mathrm{C}$ $(\mathrm{Ctrl}+\mathrm{C})$ di keyboard (ini untuk meng-copy tulisan). Selanjutnya untuk mempaste (memunculkan tulisan di halaman lain) caranya cukup buka file Ms. Word yang akan menjadi tempat menyimpan (mempaste) lalu setelah itu klik dulu di baris dimana kita akan meletakkan kalimat yang kita copy, selanjutnya tinggal tekan $\mathrm{Ctrl}+\mathrm{V}$. Bisa juga dengan cara blok dulu kalimtanya lalu klik kanan di mouse lalu pilih “Copy'. Demikian juga kalau mau dipaste, diblok lalu klik kanan dan pilih menu 'Paste'

- Cara Blok Tulisan: Cara ini dilakukan untuk memilih kata, kalimat, atau paragraf tertentu yang akan diedit, apakah itu mengganti jenis hurufnya, memperbesar atau memperkecil tulisannya, mengcopy atau apa pun tujuannya. Yang jelas ini dilakukan untuk tujuan menentukan kata tertentu yang akan diubah atau diedit. Caranya cukup klik di bagian depan kata atau kalimatnya lalu tekan dan jangan dilepas, selanjutnya tinggal tarik kursornya hingga ke bagian akhir yang akan diblok.

\section{Panduan Dasar Ms. Excel}

Untuk memulai menggunakan aplikasi Microsoft Excel, ada beberapa cara yang bisa gunakan diantaranya adalah sebagai berikut :

Cara Pertama

- Nyalakan Komputer terlebih dahulu

- Klik tombol Start pada Taskbar Komputer

- Pilih menu All Program, Pilih Microsoft Office

- Kemudian klik Microsoft Excel Cara Kedua

- Nyalakan Komputer terlebih dahulu

- Double Klik icon Microsoft Excel 
yang ada pada Desktop Komputer

Anda.

Cara Ketiga

- Nyalakan Komputer terlebih dahulu

- Tekan kombinasi tombol

Windows (bendera di pojok

kiri bawah) dan tombol $\mathrm{R}$

secara bersamaan

(Wndows+R), maka akan

muncul kotak dialog kecil di

pojok kiri bawah.

- Ketikkan Excel kemudian tekan tombol Enter.

\section{Panduan Dasar Ms. PowerPoint}

Untuk memulai menggunakan Microsoft PowerPoint dengan langkah-langkah berikut:

- klik icon Microsoft PowerPoint di desktop anda atau pergi ke Start Menu > All Programs> Microsoft Office > Microsoft PowerPoint

- Menyimpan File Penting: Untuk menyimpan file klik File > Save As kemudian beri nama file yang akan disimpan, jika sudah klik tombol save.

- Format Slide: Banyak cara untuk memulai membuat Slide yang kita inginkan. Pertama, jika kita bingung tentang desain file presentasi yang kita kerjakan ada satu cara yang telah disediakan oleh Microsoft untuk memudahkan penggunanya memulai sebuah tugas. Pada Toolbar pilih Design > Themes Jika sudah kemudian pilih tema slide yang disukai maka program akan secara otomatis mengatur tampilan desain tema yang dipilih. Untuk mengganti layout (tampilan tata letak) file presentasi bisa dengan memilih Home > Layout Gambar

- Mendesain atau Mengubah Tampilan Latar Dokumen: untuk membuat file presentasi yang mengharuskan kita untuk mendesain dokumen tersebut sesuai permintaan (khusus), seperti tema penyuluhan narkoba, penyuluhan pentingnya kesehatan. Hal ini sangat mudah. Hal yang perlu kita lakukan adalah hanya mengganti atau menukar objek gambar latar pada dokumen dengan Cara klik kanan di slide utama file $>$ Format Background Lalu pilih Fill > Picture or texture fill > file kemudian pilih file gambar untuk dijadikan background, usahakan gambar yang tidak terlalu kontras dengan tulisan sehingga indah dan mudah untuk dibaca.

- Memberi atau Menambah Objek/Gambar: Untuk memperindah dan membuat dokumen presentasi 
menjadi menarik sehingga tidak membuat hadirin merasa bosan, ada baiknya jika dokumen presentasi tidak hanya memuat tulisan saja. Penambahan objek atau gambar dapat berguna untuk memperindah dan memperjelas suatu materi yang akan disampaikan pada saat presentasi. Ada beberapa perintah yang bisa digunakan untuk memberi atau menambah objek/gambar yaitu dengan Clip Art, Word Art, Pictures, Table, Charts. 1. Clip Art 6.

Pelaksanaan kegiatan Pengabdian kepada Masyarakat ini berupa pelatihan Microsoft Office (Word, Excel dan PowerPoint) pada warga pengambangan yang ikut Program Paket C PKBM Az Zahra Kota Banjarmasin diharapkan peserta dapat memiliki kompetensi pengetahuan dan keterampilan komputer Microsoft Office.

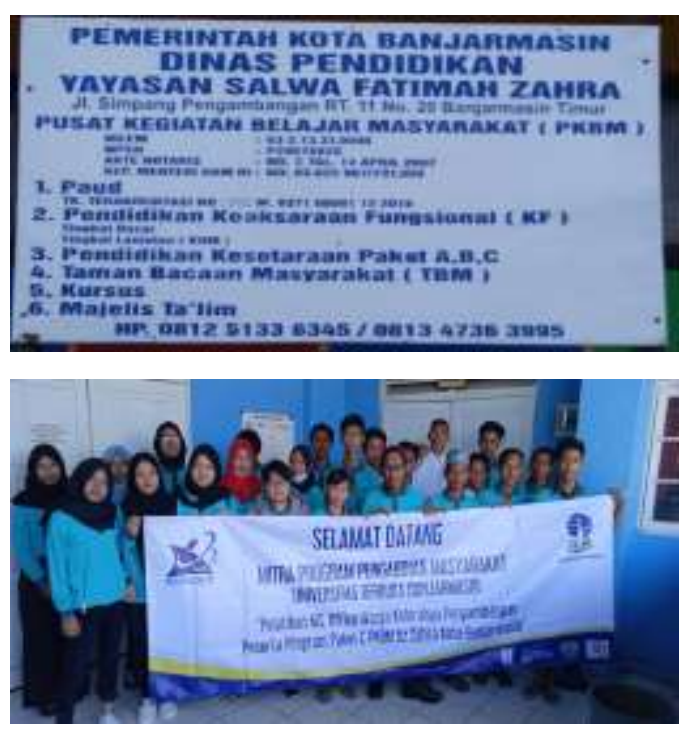

\section{KESIMPULAN}

Dari rangkaian proses Kegiatan pengabdian kepada masyakarat pada tahun 2020 Program Paket C di PKBM Az Zahra yang telah dilaksanakan, menghasilkan :

1. Pelaksanaan Pelatihan Microsoft Office (Word, Excel dan PowerPoint) pada Program Paket C PKBM Az Zahra dapat terlaksana dengan baik sesuai dengan waktu dan tempat yang telah direncakan sebelumnya.

2. Pelaksanakan Pelatihan Microsoft Office (Word, Excel dan PowerPoint) terhadap peserta Program Paket C PKBM Az Zahra untuk membekali pengetahuan dan keterampilan Komputer Microsoft Office sebagai bekal dalam memasuki dunia kerja.

\section{DAFTAR PUSTAKA}

Farida, M. (2017). Pemanfaatan Microsoft Word dalam Pembuatan Karya Ilmiah bagi Guru di MTs. Al-Furqon Banjarmasin. Jurnal Pengabdian Al Ikhlas, Vol 2 No 2, 20-22

Farida, M. (2019). Pelatihan Penggunaan Microsoft Excel untuk Perhitungan Nilai Siswa pada MTs. Al-Furqon Banjarmasin. Jurnal Pengabdian Al Ikhlas, Vol 5 No 1, 96-100

Irmayani. (2019). Pengembangan Sumber Daya Manusia Melalui Pelatihan Microsoft Office Pada Aparat Desa di Kecamatan 
Lamasi Timur Kabupaten Luwu Provinsi Sulawesi Selatan. Abdimas Toddopuli : Jurnal Pengabdian pada Masyarakat, Vol 1 No 1, 20-27

Karyadiputra, E. (2019). Pengembangan Kreativitas Anak Asuh Berbasis TI dalam Menanamkan Nilai Wirausaha pada Asrama Putera Panti Asuhan Yatim Piatu dan Dhu'afa Yayasan Al-Ashr Banjarmasin. Jurnal Pengabdian Al Ikhlas, Vol 4 No 2, 186-190

Muin, Alim A. (2019). PKMS Peningkatan Kompetensi Guru dan Pengembangan Perangkat Pembelajaran Berbasis IT Guna Menunjang Pelaksanaan Kurikulum 2013 pada SMP Negeri 1 Anjir Pasar Desa Anjir Pasar Kota Ii Kec. Anjir Pasar Kab. Batola. Jurnal Pengabdian Al Ikhlas, Vol 5 No 1, 78-86

Niati, A. (2019). Pengembangan Kemampuan Sumber Daya Manusia melalui Pelatihan
Komputer Microsoft Office Excel untuk Meningkatkan Kinerja. E-DIMAS Jurnal Pengabdian kepada Masyarakat, Vol 10 No 1, 105-110

Pratiwi, H.I. (2018). Pelatihan Microsoft Office untuk Karyawan dan Kelompok PKK Kelurahan Sawah Baru Tangerang Selatan. Sembadha 2018, Vol 01 Edisi 01, 8-13

Pusat Bahasa Departemen Pendidikan Nasional. (2002). Kamus Besar Bahasa Indonesia. Jakarta : Balai Pustaka.

Soekidjo Notoatmodjo. (2003). Pendidikan dan Perilaku Kesehatan. Jakarta : PT Rineka Cipta.

.Undang-undang Republik Indonesia Nomor 20 Tahun 2003 Tentang Sistem Pendidikan Nasional. 